\title{
Changes in the metabolic balance of contrasting microbial food webs after nutrient enrichment
}

\author{
S. Martínez-García* , E. Teira, E. Fernández \\ Departamento Ecoloxía e Bioloxía Animal, Universidade de Vigo, Campus Lagoas-Marcosende, 36310 Vigo, Spain
}

\begin{abstract}
Two sets of inorganic (nitrate, ammonium, phosphate) and/or organic (glucose, amino acids) nutrient addition experiments were performed in contrasting planktonic ecosystems, including both oligotrophic central Atlantic waters and mesotrophic coastal waters off the NW Iberian Peninsula, to assess the direction and magnitude of the shifts in the metabolic balance, defined as the primary production to community respiration ratio $(P / R)$, of different microbial plankton communities. Large $(>2 \mu \mathrm{m})$ phytoplankton accounted for most of the primary production response to nutrient additions in all the microbial plankton communities studied. Microbial plankton metabolic shifts after inorganic or organic nutrient additions appeared to be dependent on both the production and biomass size structure of phytoplankton communities. The strongest tendencies towards short-term autotrophy (after inorganic additions) and heterotrophy (after organic additions) were registered in microbial communities initially dominated by large phytoplankton cells (i.e. herbivore food webs) with high and low relative contribution of large cells to primary production, respectively, suggesting that the metabolic balance of herbivore food webs is less resistant to nutrient additions than that of microbial food webs (dominated by picophytoplankton). By contrast, regardless of the trophic structure of phytoplankton populations, the shortterm response of the microbial plankton metabolic balance to the combined inorganic and organic nutrient additions appeared to be mainly related to the initial $P / R$ ratios, which implies that the more heterotrophic the microbial community, the stronger the tendency towards heterotrophy after mixed additions.
\end{abstract}

KEY WORDS: Microbial plankton · Nutrient amendments

Resale or republication not permitted without written consent of the publisher

\section{INTRODUCTION}

Knowledge of the microbial plankton metabolic balance provides valuable information about energetics and carbon processing through planktonic food webs and, ultimately, contributes to the understanding of the global carbon cycle. Different patterns of organic matter circulation in the upper ocean are associated with differences in the structure and functioning of the planktonic food web that is controlled by both top-down (i.e. grazing at different levels of the food webs) and bottom-up processes (i.e. nutrient availability) (Legendre \& Rassoulzadegan 1996, Calbet \& Laundry 2004, Vargas et al. 2007).
There is a higher potential for growth of larger phytoplankton cells when nutrients are available (Thingstad \& Sakshaug 1990, Agawin et al. 2000, Cermeño et al. 2005). The relationship between phytoplankton size-structure and the metabolic balance of microbial communities (production/respiration ratio, $P / R$ ) has been widely demonstrated in different marine ecosystems (Serret et al. 2001, Smith \& Kemp 2001, Teira et al. 2001a,b). Microbial communities in which phytoplankton biomass is dominated by large phytoplankton cells are characterized by herbivore food chains, important prevailing export processes and net autotrophic metabolisms $(P / R>1)$ (Steele 1976, Legendre 1990, Thingstad \& Sakshaug 
1990, Kiørboe 1996, Legendre \& Rassoulzadegan 1996). In contrast, in those communities where picophytoplankton biomass accounts for a high fraction of total phytoplankton biomass, and both biomass and photosynthetic carbon fixation are low, important remineralization processes prevail (i.e. microbial food webs) (Azam et al. 1983, Platt et al. 1983, Sherr \& Sherr 2000, Fenchel 2008). These communities are also associated with higher respiration rates compared to primary production rates, which results in net balanced $(P / R=1)$ or even net heterotrophic $(P / R$ $<1)$ metabolisms. Net heterotrophy of these communities has been argued to be maintained by aperiodic bursts of oxygen accumulation (Karl et al. 2003) that would be resource-controlled by different nutrient delivery mechanisms (McGillicuddy et al. 1998, Uz et al. 2001, Gregg et al. 2003, Baker et al. 2007). Microbial communities in these areas have been hypothesized to utilize these intermittent nutrient inputs and presumably become net autotrophic during short but frequent periods of time (Karl et al. 2003).

Allochthonous nutrient additions, such as atmospheric inputs, affect both autotrophic and heterotrophic rates (Michaels et al. 1993, Mills et al. 2004, Bonnet et al. 2005, Herut et al. 2005, Pulido-Villena et al. 2008, Reche et al. 2009), but most investigations on the effects of nutrient inputs on microbial communities have focused either on the autotrophic or the heterotrophic compartments (e.g. Graziano et al. 1996, Carlson et al. 2002, Mills et al. 2004, Piehler et al. 2004, Bonnet et al. 2005, Moore et al. 2006, 2008). Investigations addressing the joint effect of inorganic and organic nutrients on both microbial compartments are still scarce (Thingstad et al. 1999, Joint et al. 2002, Davidson et al. 2007, MartínezGarcía et al. 2010a,b). Only a few recent works have paid attention to possible shifts in the metabolic balance of microbial communities after natural (Lekunberri et al. 2010, Marañón et al. 2010) or controlled nutrient inputs (Thingstad et al. 1999). In addition, very little is known about the factors modulating the metabolic balance responses of distinct microbial communities to different nutrient inputs. As far as we know the present study is the first one that specifically addresses the changes in metabolic balance promoted by inorganic and/or organic nutrients in microbial communities with different trophic structures.

The aim of the present study was to investigate the direction and magnitude of $P / R$ shifts after inorganic and/or organic nutrient inputs in contrasting microbial plankton communities. More specifically, we first hypothesized that large $(>2 \mu \mathrm{m})$ phytoplankton cells would outcompete small cells after nutrient additions, thus, herbivore food webs are expected to experience a stronger tendency to autotrophy after inorganic nutrient inputs than microbial food webs. Secondly, we hypothesized that microbial food webs, dominated by small phytoplankton and with initial net balanced or net heterotrophic metabolisms, would experience a stronger tendency to heterotrophy after organic nutrient inputs compared to herbivore food webs (initially net autotrophic).

With this purpose we studied the changes in $P / R$ ratios promoted by nutrient additions in 2 sets of experiments performed in open-ocean and coastal waters (Martínez-García et al. 2010a,b) in order to describe general microbial response patterns of metabolic balance to nutrient loading. This comprehensive study allowed us to derive some conclusions of relevance for the understanding of microbial food web functioning.

\section{MATERIALS AND METHODS}

\section{Survey areas}

The 2 sampling sites visited in the present study are shown in Fig. 1. The oligotrophic regions of the central Atlantic Ocean are characterized by strong thermal stratification and nutrient depletion in the upper mixed layer over most of the year, which translates into very low levels of chlorophyll $a$ and primary production, dominance of $<2 \mu \mathrm{m}$ picophytoplankton cells and, hence, prevalence of microbial food webs (Marañón et al. 2001, Teira et al. 2006, Fenchel 2008). Five experiments (Expt 1 to 5) were performed in November and December 2007 along a latitudinal transect (approximately from $26^{\circ} \mathrm{N}$ to $29^{\circ} \mathrm{S}$ latitude).

By contrast, the Ría de Vigo (Spain) is a mesotrophic embayment located in the coastal system of the NW Iberian Peninsula, a highly productive and dynamic coastal ecosystem (Cermeño et al. 2006), characterized by the upwelling (from March to September) of cold and nutrient-rich North Atlantic Central Water (NACW) (Nogueira et al. 1997). Large phytoplankton cells $(>2 \mu \mathrm{m})$ dominate the autotrophic community, especially during upwelling periods when $>20 \mu \mathrm{m}$ cells represent $>80 \%$ of the phytoplankton community and herbivore food webs prevail (Legendre 1990, Cermeño et al. 2006). Three experiments were performed at an on-shelf station (Shelf) (Expt 6 to 8) and 3 at a station located in the middle sector of the ría (Ría) (Expt 9 to 11). Experiments were performed from February to July 2008. 


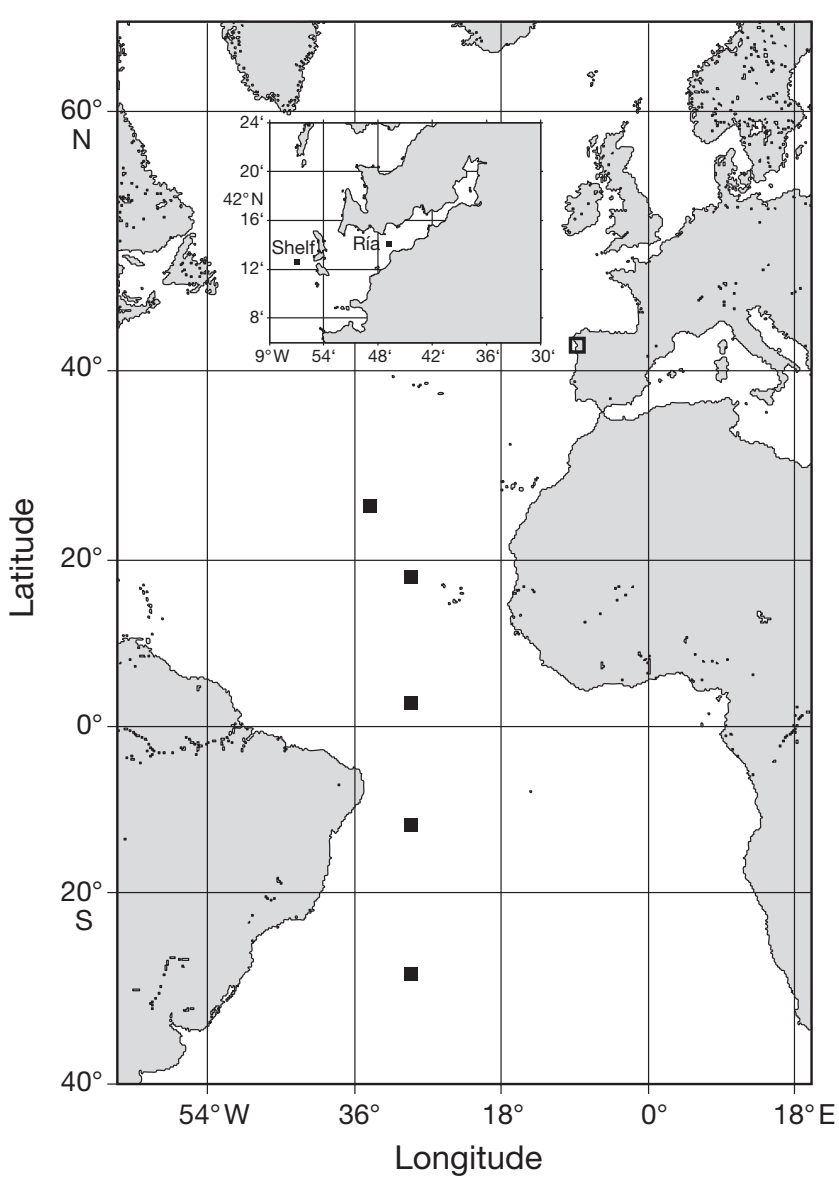

Fig. 1. Locations of the sampled stations $(\boldsymbol{\square})$ in the central Atlantic Ocean and along the Iberian coastal margin. Inset: detailed map of the coastal embayment

\section{Experimental setup}

Vertical profiles down to $300 \mathrm{~m}$, and between 25 and $75 \mathrm{~m}$ (open and coastal ocean stations, respectively) of water column temperature, salinity and in situ fluorescence were obtained with a SBE 9/11 CTD probe and Seatech fluorometer attached to a rosette sampler. Surface seawater samples (5 to $10 \mathrm{~m}$ ) were collected in 12 or 151 acid-clean Niskin bottles and filtered through a 150 and $200 \mu \mathrm{m}$ pore size mesh (open-ocean and coastal stations, respectively) to remove larger zooplankton. Subsequently, 12 l acid-washed polycarbonate bottles were gently filled under dim light conditions.

Following sample collection, nutrients were added to the microcosm bottles. The experimental design included duplicate 121 bottles for a series of 4 treatments (Table 1): (1) control treatment, (2) inorganic addition treatment, (3) organic addition treatment and (4) mixed addition treatment. Glucose and amino acids (equimolar mixture of 18 amino acids: all protein amino acids, except cysteine and tyrosine) were included, as they are among the most abundant organic labile substances identified in seawater (Cauwet 2002). Dissolved amino acids represent $13.1 \%$ of total dissolved organic nitrogen (DON) $(7.2$ and $5.9 \%$ from dissolved combined and dissolved free amino acids, respectively) (Bronk 2002) and hydrolyzable neutral sugars represent 2 to $6 \%$ of the total dissolved organic carbon (DOC) pool (Benner 2002). The magnitude of the additions performed was chosen to be in excess of the mean concentrations measured in the surface waters of each ecosystem (Álvarez-Salgado et al. 1996, Marañón et al. 2001). The added nutrient concentrations were 10fold higher in the coastal experiments than in the open-ocean experiments (20-fold in the case of $\mathrm{HPO}_{4}{ }^{2-}$ ), in accordance with the differences in the mean initial nutrient concentrations, standing stocks and metabolic rates between both ecosystems (see initial conditions in Table 2).

The N/P ratios of the additions performed were different in open-ocean (N/P $=20: 1$ to 30:1 inorganic and mixed additions, respectively) and coastal experiments (N/P $=10: 1$ to 15:1 inorganic and mixed additions, respectively) in order to compensate for the low initial N/P ratios in surface oligotrophic waters of the central Atlantic (0 to 3; Fanning 1992) compared to the mean N/P ratio of surface waters off the Iberian coastal margin (10 to 18; Álvarez-Salgado et al. 1997, Prego et al. 1999) (see Table 2).

In both cases, temperature was maintained within $\pm 0.1^{\circ} \mathrm{C}$ of in situ temperature. Bottles were illuminated with cool white light from fluorescent tubes (photoperiod 10 to $12 \mathrm{~h}$ light:12 to $14 \mathrm{~h}$ dark and the average photosynthetically active radiation [PAR] was $240 \mu \mathrm{E} \mathrm{m}^{-2} \mathrm{~s}^{-1}$ ). Experiments lasted $3 \mathrm{~d}$, and sam-

Table 1. Nutrient additions performed in each of the experimental treatments tested in both open-ocean and coastal environments. Glc: glucose; AA: amino acids

\begin{tabular}{|lcccccc|}
\hline Treatment & $\begin{array}{c}\mathrm{NO}_{3}{ }^{-} \\
(\mu \mathrm{M})\end{array}$ & $\begin{array}{c}\mathrm{NH}_{4}{ }^{+} \\
(\mu \mathrm{M})\end{array}$ & $\begin{array}{c}\mathrm{HPO}_{4}{ }^{2-} \\
(\mu \mathrm{M})\end{array}$ & $\begin{array}{c}\mathrm{SiO}_{4}{ }^{2-} \\
(\mu \mathrm{M})\end{array}$ & $\begin{array}{c}\mathrm{GlC} \\
(\mu \mathrm{M})\end{array}$ & $\begin{array}{c}\mathrm{AA} \\
(\mu \mathrm{M})\end{array}$ \\
\hline $\begin{array}{l}\text { Inorganic } \\
\text { Open }\end{array}$ & 0.5 & 0.5 & 0.05 & 0.1 & & \\
Coastal & 5 & 5 & 1 & & & \\
$\begin{array}{l}\text { Organic } \\
\begin{array}{l}\text { Open } \\
\text { Coastal }\end{array}\end{array}$ & & & & & & \\
$\begin{array}{l}\text { Mixed } \\
\text { Open } \\
\text { Coastal }\end{array}$ & 0.5 & 0.5 & 0.05 & 0.1 & 0.5 & 0.5 \\
& 5 & 5 & 1 & & 5 & 5 \\
\hline
\end{tabular}


ples were taken every $24 \mathrm{~h}$ to monitor changes in microbial community structure and metabolism.

\section{Chemical and biological analyses}

A complete methodological description is provided in Martínez-García et al. (2010a,b); here we provide a short outline.

Inorganic and organic nutrients. For the openocean experiments nitrate and ammonium concentrations were determined on-board on fresh samples with a Technicon segmented-flow auto-analyser and using modified colorimetric protocols that allow a detection level of $2 \mathrm{nmol} \mathrm{l}^{-1}$ (Raimbault et al. 1990, Kerouel \& Aminot 1997). Phosphate concentrations were determined using standard procedures (Tréguer $\&$ Le Corre 1975). For the coastal experiments, inorganic nutrient determination (ammonium, nitrite, nitrate, phosphate, silicate) was performed by standard colorimetric methods with an Alpkem segmented-flow analyzer (Hansen \& Grasshoff 1983).

Size-fractionated chlorophyll a. Chlorophyll a (chl a) fluorescence was determined using the non-acidification technique with a TD-700 Turner Designs fluorometer calibrated with pure chl a.

Primary production. Size-fractionated primary production (PP) was estimated by assessing ${ }^{14} \mathrm{C}$ incorporation by phytoplankton cells (Marañón et al. 2001). Primary production incubations lasted 3 to $4 \mathrm{~h}$ in the coastal experiments and 12 to $14 \mathrm{~h}$ in the openocean experiments. The PP to community respiration $(\mathrm{CR})$ ratio $(P / R)$ was calculated from daily gross $\mathrm{PP}$ rates estimated using a correction factor for phytoplankton respiration of $20 \%$ and a percentage of extracellular release (PER) of 20\% (Marañón et al. 2004).

Flow cytometry. The abundance of heterotrophic bacteria was determined with a Becton Dickinson FACSCalibur flow cytometer equipped with a laser emitting at $488 \mathrm{~nm}$ (Gasol \& del Giorgio 2000).

Bacterial heterotrophic production. The $\left[{ }^{3} \mathrm{H}\right] l e u-$ cine incorporation method (Kirchman et al. 1985), modified as described by Smith \& Azam (1992), was used to determine leucine (Leu) incorporation rates (LIR). Bacterial production (BP) incubations lasted $1 \mathrm{~h}$ in the coastal experiments and 1.5 to $2 \mathrm{~h}$ in the open-ocean experiments. Dilution experiments were performed in both sets of experiments in order to determine empirical leucine to carbon conversion factors ( $\mathrm{CF}$ ) following methods detailed elsewhere (Calvo-Díaz \& Morán 2009). CF ranges

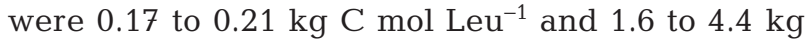

$\mathrm{C}$ mol Leu ${ }^{-1}$ for the open-ocean and coastal experiments, respectively.

In vivo electron transport system (ETS). ETS activity rate was used as an estimator of CR. In vivo ETS activity rates were measured using the in vivo INT method (Martínez-García et al. 2009). ETS activity incubations lasted $1 \mathrm{~h}$ in the coastal experiments and 4 to $6 \mathrm{~h}$ in the open-ocean experiments. In order to transform ETS activity into carbon respiration an R/ETS ratio of 12.8 (Martínez-García et al. 2009) and a respiratory quotient (RQ) of 0.8 (Williams \& del Giorgio 2005) were used.

\section{Data analysis}

In the present study, experiments lasted $3 \mathrm{~d}$, and rates and biomasses were measured every $24 \mathrm{~h}$. To study the effect of different nutrient additions on microbial standing stocks and metabolic rates, we calculated response ratios (RR) as an effect-size metric (Downing et al. 1999, Hedges et al. 1999, Elser et al. 2007). Response ratios ( $R R=A T / C)$ were calculated by dividing the time-integrated (i.e. from 0 to $72 \mathrm{~h}$ ) value in the addition treatment (AT) by the time-integrated value in the control (C). In the case of standing stocks and ratios, time-averaged values were used.

t-test analyses were conducted to test for mean response ratios significantly different from 1 in the different addition treatments in each set of experiments. All datasets fitted a normal distribution (Kolmogorov-Smirnov test), and data transformation was not necessary.

Type II (reduced major axis) regression was used (Sokal \& Rohlf 1995) for the relationship between the logarithms of the response ratios of chl $a>2 \mu \mathrm{m}$ (chl $a$ $>2 \mu \mathrm{m}_{\mathrm{RR}}$ ) and chl $a<2 \mu \mathrm{m}\left(\mathrm{chl} a<2 \mu \mathrm{m}_{\mathrm{RR}}\right)$ and the logarithm of the response ratio of primary production $\left(\mathrm{PP}_{\mathrm{RR}}\right)$ as these variables had an associated error.

\section{RESULTS AND DISCUSSION}

Mean initial conditions for the 2 sets of experiments are presented in Table 2 . Contrasting nutrient conditions and planktonic food web structures and metabolic rates were encountered in open-ocean and coastal ocean environments. Nutrient concentrations were circa 1 order of magnitude higher in the coastal area than at the open-ocean sites (2 orders of magnitude in the case of ammonium and nitrite). The trophic structure of phytoplankton communities 
greatly differed between the 2 areas. Picophytoplankton $(<2 \mu \mathrm{m})$ cells dominated the initial autotrophic community (\%chl $a<2 \mu \mathrm{m}=57.9 \pm 2.6)$ in open-ocean experiments (microbial food webs), while the coastal phytoplankton community was dominated by large cells $(>2 \mu \mathrm{m})(\% \mathrm{chl} a>2 \mu \mathrm{m}=$ $95 \pm 1.4 \%$ ) (herbivore food webs). The mean initial metabolic balance was net heterotrophic in microbial communities from open-ocean sites $(P / R=0.66 \pm$ $0.19)$ and net autotrophic in coastal microbial communities $(P / R=1.61 \pm 0.35)$. It is important to note here that, as already explained in 'Materials and methods', the same correction factor for phytoplankton respiration (i.e. $20 \%$ ), the same PER (i.e. $20 \%$; Marañón et al. 2004) and the same RQ (i.e. 0.8; Williams \& del Giorgio 2005) were used for both datasets.

A summary of the biomasses and averaged metabolic responses to the addition treatments in both ecosystems (Martínez-García et al. 2010a,b) is presented in Table 3. Phytoplankton responses ( $\mathrm{chl} a_{\mathrm{RR}}$ and $\mathrm{PP}_{\mathrm{RR}}$ ) after mixed additions were significant only in herbivore food webs. In the open-ocean experiments picoeukaryotes were the group most benefitting from the additions, to the detriment of Prochlorococcus (Martínez-García et al. 2010a). In the coastal experiments phytoplankton community composition did not greatly change as a result of the nutrient additions. Diatoms and dinoflagellates dominated the phytoplankton community at the end of the experiments (Martínez-García et al. 2010b).

Heterotrophic bacteria $\left(\mathrm{BB}_{\mathrm{RR}}\right.$ and $\left.\mathrm{BP}_{\mathrm{RR}}\right)$ and community respiration $\left(\mathrm{CR}_{\mathrm{RR}}\right)$ responses after organic and mixed additions were significant in both ecosystems. The mean magnitude of change in metabolic balance $\left(P / R_{\mathrm{RR}}\right)$ was significant after organic additions in both ecosystems, while mixed additions promoted significant changes in metabolic balance only in microbial food webs.

It is worth noting that prefiltration (150 and $200 \mu \mathrm{m}$ pore size mesh in open-ocean and coastal experiments, respectively) of the samples could partially re-

Table 2. Initial conditions for each set of experiments. Microbial food webs occurred in the open ocean $($ Expt $1-5, \mathrm{n}=10)$ $\left(26^{\circ} \mathrm{N}-29^{\circ} \mathrm{S}\right.$ Atlantic Ocean); Herbivore food webs occurred in the coastal ocean (Expt 6-11, $\left.\mathrm{n}=12\right)($ NW Iberian Peninsula). Sampling depth was 5 to $10 \mathrm{~m}$

\begin{tabular}{|c|c|c|}
\hline Parameter & Microbial food webs & Herbivore food webs \\
\hline $\mathrm{NO}_{3}^{-}\left(\mu \mathrm{mol} l^{-1}\right)$ & $0.117 \pm 0.002$ & $3.2 \pm 1.2$ \\
\hline $\mathrm{NO}_{2}^{-}\left(\mu \mathrm{mol} \mathrm{l} l^{-1}\right)$ & $0.0024 \pm 0.0003$ & $0.27 \pm 0.11$ \\
\hline $\mathrm{NH}_{4}^{+}\left(\mu \mathrm{mol} \mathrm{l} l^{-1}\right)$ & $0.016 \pm 0.001$ & $1.9 \pm 0.7$ \\
\hline $\mathrm{PO}_{4}{ }^{3-}\left(\mu \mathrm{mol} \mathrm{l}{ }^{-1}\right)$ & $0.05 \pm 0.009$ & $0.36 \pm 0.16$ \\
\hline N/P ratio & $3.2 \pm 0.5$ & $24.3 \pm 5.3$ \\
\hline Chlorophyll a (chl $\left.a, \mu g \mathrm{l}^{-1}\right)$ & $0.18 \pm 0.02$ & $1.1 \pm 0.3$ \\
\hline$\%$ Chl $a>2 \mu \mathrm{m}$ & $42.0 \pm 2.6$ & $95.0 \pm 1.4$ \\
\hline Primary production $\left(\mathrm{PP}, \mu \mathrm{g} \mathrm{C} \mathrm{l}^{-1} \mathrm{~h}^{-1}\right)$ & $0.07 \pm 0.02$ & $2.4 \pm 0.5$ \\
\hline$\% \mathrm{PP}>2 \mu \mathrm{m}$ & $66.4 \pm 5.8$ & $85.1 \pm 7.8$ \\
\hline Bacterial biomass (BB, $\left.\mu \mathrm{g} \mathrm{C} \mathrm{l}^{-1}\right)$ & $4.1 \pm 0.6$ & $20.0 \pm 2.8$ \\
\hline 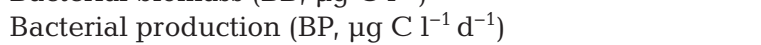 & $0.09 \pm 0.02$ & $13.1 \pm 2.3$ \\
\hline 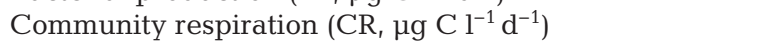 & $2.8 \pm 0.9$ & $26.6 \pm 3.5$ \\
\hline Primary production to community respiration ratio $(P / R)$ & $0.66 \pm 0.19$ & $1.61 \pm 0.35$ \\
\hline
\end{tabular}

Table 3. Mean response ratios (RR) and standard errors of the different variables studied for both sets of experiments and for the 3 addition treatments. Asterisks indicate ratios significantly different from 1, i.e. significant responses to the additions: ${ }^{*} \mathrm{p}<$ $0.05 ;{ }^{* *} \mathrm{p}<0.01{ }^{* * *} \mathrm{p}<0.001$. Details and abbreviations as in Table 2

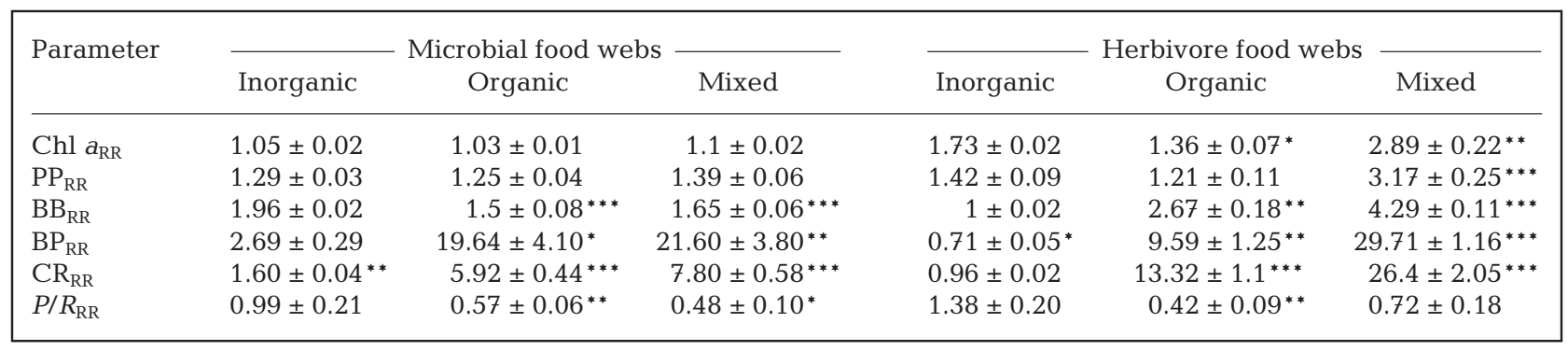


lease ciliates and heterotrophic flagellates from predators, thus enhancing grazing pressure by microbial protists on small phytoplankton and bacteria. In those open-ocean experiments in which no important phytoplanktonic responses were found after the nutrient enrichments, the $\mathrm{PP} / \mathrm{chl}$ a ratio increased after the first incubation day, suggesting that the decrease of the chl a concentration could be caused by top-down control of phytoplankton at these stations (MartínezGarcía et al. 2010a). The lack of phytoplankton response to the additions in one of the coastal experiments was related to the low initial photosynthetic efficiency measured rather than to strong grazing control, since large phytoplankton, which mostly dominated the phytoplankton community in those experiments, would presumably not be severely grazed in this $200 \mu \mathrm{m}$ prefiltered water (Martínez-García et al. 2010b). Heterotrophic bacterial metabolic rates (bacterial production and bacterial respiration) responded considerably more than bacterial biomass, likely related to a strong top-down control (i.e. predation) (Martínez-García et al. 2010a,b).

When pooling the available data from the 11 experiments, a significant relationship $\left(\mathrm{r}^{2}=0.66, \mathrm{p}<0.001\right.$, $\mathrm{n}=33$ ) was found between the responses of $\mathrm{PP}\left(\mathrm{PP}_{\mathrm{RR}}\right)$ and the responses of the chl $a>2 \mu \mathrm{m}$ size fraction (chl $a>2 \mu \mathrm{m}_{\mathrm{RR}}$ ) to the nutrient addition treatments (Fig. 2A). The more intense the magnitude of the response of large-sized phytoplankton $(>2 \mu \mathrm{m})$ to any of the nutrient addition treatments, the higher the response of primary production to the same nutrient inputs. By contrast, no significant relationship was encountered between $\mathrm{PP}_{\mathrm{RR}}$ and the responses of the $<2 \mu \mathrm{m}$ chl a size fraction (chl $a<2 \mu \mathrm{m}_{\mathrm{RR}}$ ) (Fig. 2B). This may be related to the higher nutrient uptake efficiency and, therefore, potential for growth of larger phytoplankton cells when nutrients are available (Thingstad \& Sakshaug 1990, Agawin et al. 2000, Cermeño et al. 2005). Thus, when nutrients are available, large phytoplankton cells outcompete small cells whatever the size-structure of the initial autotrophic community. Accordingly, it is expected that those communities dominated by large phytoplankton would tend to become more autotrophic after inorganic nutrient inputs than those dominated by small phytoplankton. Nevertheless, the stronger response of large phytoplankton cells to nutrient amendments could also be related to lower grazing pressure on these cells compared to that on small phytoplankton due to the removal of large zooplankton in these experiments.

Initial $P / R$ ratios (black isolines) were represented over a production/biomass $(P / B)$ plot (Tremblay \& Legendre 1994) (Fig. 3). The $P / B$ plot shows initial modes of phytoplankton production and trophic structures according to the relative contribution of $>2 \mu \mathrm{m}$ phytoplankton to biomass (\%chl a $>2 \mu \mathrm{m}$ ), represented on the $x$-axis and to primary production $(\% \mathrm{PP}>2 \mu \mathrm{m})$ represented in the $y$-axis. Initial $P / R$ ratios $\left(P / R_{\mathrm{i}}\right)$ were found to increase as the $\% \mathrm{PP}>2 \mu \mathrm{m}$ increases (Fig. 3), which is in accordance with the previously observed influence of phytoplankton production size-structure on the degree of heterotrophy of marine plankton ecosystems (Serret et al. 2001, Smith \& Kemp 2001, Teira et al. 2001a,b). By contrast, no relation between the $P / R_{\mathrm{i}}$ and the initial \% chl $a>2$ $\mu \mathrm{m}$ can be observed, which results from the lack of relationship between the contribution of large phytoplankton to total chl $a$ and to total primary production $\left(\mathrm{p}>0.05, \mathrm{r}^{2}=0.25\right)$ across the dataset, indicating that the phytoplankton communities sampled in the present study showed distinct balances between produc-
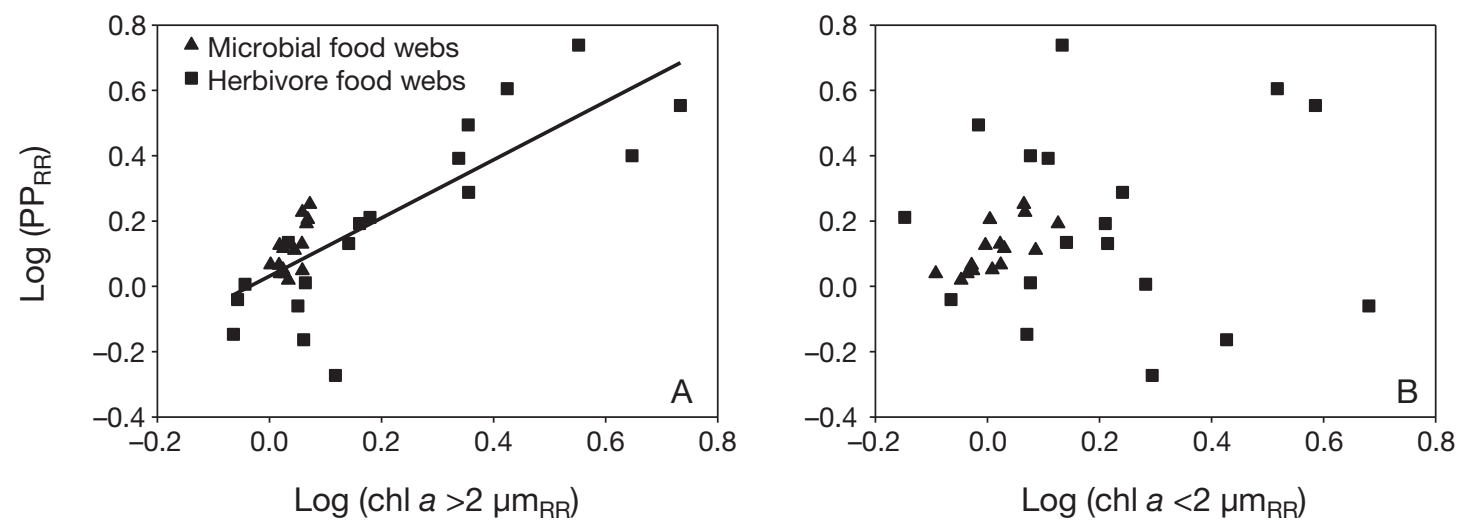

Fig. 2. Log-Log relationship of the chlorophyll a concentration in the $(\mathrm{A})>2 \mu \mathrm{m}$ size fraction response ratio $\left(\mathrm{chl} \mathrm{a}>2 \mu \mathrm{m}_{\mathrm{RR}}\right)$ and (B) $<2 \mu \mathrm{m}$ size fraction response ratio (chl $a<2 \mu \mathrm{m}_{\mathrm{RR}}$ ) versus the primary production response ratio $\left(\mathrm{PP}_{\mathrm{RR}}\right)$. Microbial food web (closed triangles) and herbivore food web (closed squares) datasets are represented. Regression line including both datasets: $\log \left(\mathrm{PP}_{\mathrm{RR}}\right)=1.1 \times \log \left(\mathrm{chl} a>2 \mu \mathrm{m}_{\mathrm{RR}}\right)+0.002, \mathrm{r}^{2}=0.66, \mathrm{n}=33(\mathrm{p}<0.001)$ 
tion and loss terms (Tremblay \& Legendre 1994). The effect of allochthonous organic matter inputs on the net metabolism of planktonic microbial communities would be expected to be stronger in those communities initially showing a net balanced or heterotrophic metabolism, where small phytoplankton cells dominate primary production, regardless of the biomass size-structure.

Fig. 4 shows the magnitude of response of the metabolic balance $\left(P / R_{\mathrm{RR}}\right)$ to different nutrient enrichments (superimposed coloured contours), as well as the initial $P / R$ ratios (black isolines) on the production/biomass $(P / B)$ plot.

Microbial communities experienced a tendency towards short-term autotrophy after inorganic additions (Fig. $4 \mathrm{~A}$ ) in 8 out of 11 experiments, and $P / R_{\mathrm{RR}}$ ranged from 0.5 (tendency towards short-term heterotrophy) to 2.1 (tendency towards short-term autotrophy). A clearly increasing trend towards autotrophy from the left lower corner (low \%chl $a>2 \mu \mathrm{m}$ and \%PP $>2 \mu \mathrm{m}$ ) to the right upper corner (high \% chl $a>2 \mu \mathrm{m}$ and \%PP $>2 \mu \mathrm{m}$ ) was observed. This pattern of response is coherent with the observed higher potential for growth of larger phytoplankton cells when nutrients are available (Fig. 2) (Thingstad \& Sakshaug 1990, Agawin et al. 2000, Cermeño et al. 2005). Nevertheless, the increasing tendency towards short-term autotrophy appeared to be related not uniquely to the

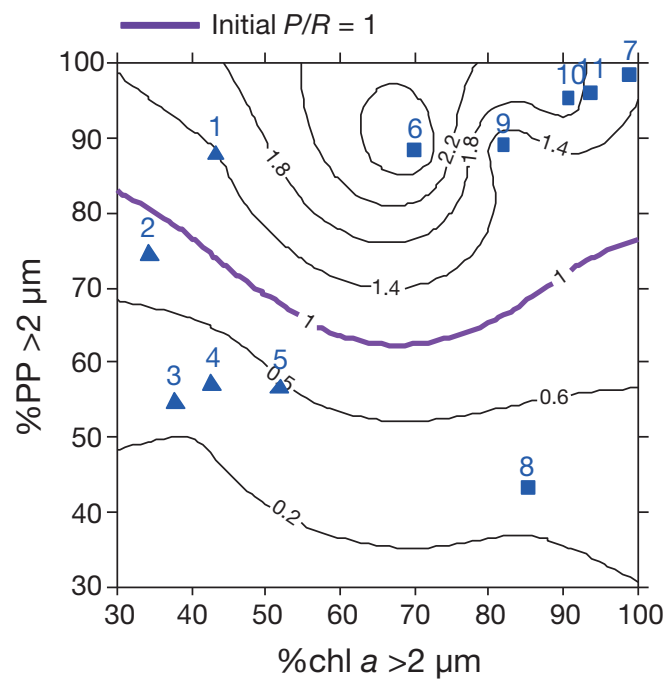

Fig. 3. Production/biomass plot: $x$ - and $y$-axes represent, respectively, the contribution of primary producers $>2 \mu \mathrm{m}$ to total phytoplankton biomass (expressed as chlorophyll a [chl a] concentration) and to primary production (PP). Symbols represent combinations of those 2 variables in different experiments (blue triangles and squares represent microbial and herbivore food webs, respectively). Isolines represent initial primary production to community respiration $(P / R)$ ratios (purple isoline: initial $P / R=1$ )
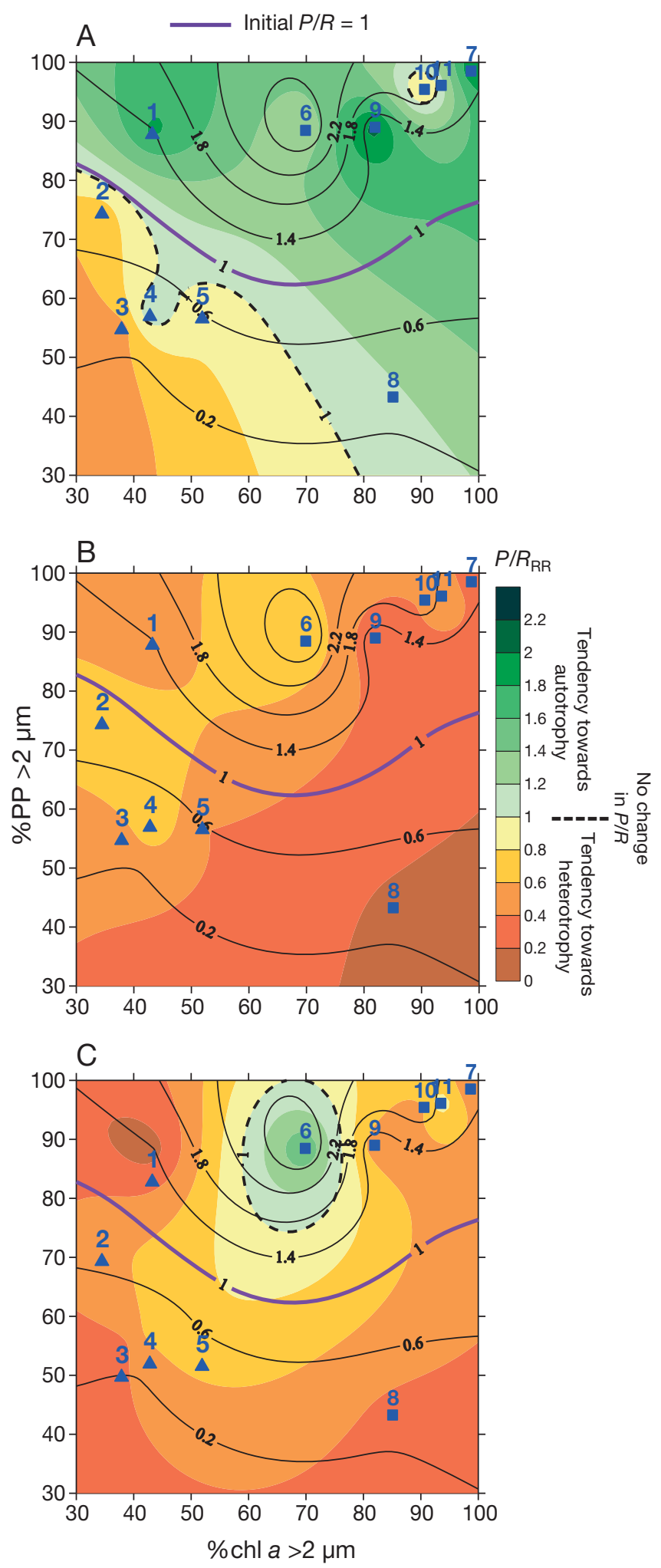

Fig. 4. As in Fig. 3. Superimposed shaded contours represent the response ratio of the $P / R$ ratio $\left(P / R_{\mathrm{RR}}\right)$ after the 3 different addition treatments: (A) inorganic treatment, (B) organic treatment and (C) mixed treatment. Dashed black line represents a $P / R_{\mathrm{RR}}$ of 1 
initial phytoplankton biomass size-structure. The microbial communities located close to the 1:1 line followed a clearly increasing trend towards autotrophy from communities dominated by small phytoplankton cells to communities dominated by large phytoplankton cells in terms of biomass. The microbial communities from Expts 1, 2 and 8 deviated considerably from the 1:1 line, showing an unbalanced contribution of large cells to biomass and production. When large cells dominate phytoplankton biomass but small phytoplankton dominates primary production (Expt 8), the $P / R_{\mathrm{RR}}$ is lower than expected from the dominance of large cells in terms of biomass. Such trophic structure was related to the accumulation of damaged or senescent large cells with a very low photosynthetic efficiency $\left(F_{\mathrm{v}} / F_{\mathrm{m}}=0.25\right)$ in the post-bloom sampled in Expt 8 (Martínez-García et al. 2010b), although it could also be related to strong grazing pressure over small phytoplankton (Tremblay \& Legendre 1994), which would explain a weaker tendency towards autotrophy than expected. On the other extreme, in Expts 1 and 2, phytoplankton biomass was dominated by small phytoplankton, whilst phytoplankton $>2 \mu \mathrm{m}$ dominated primary production, suggesting highly efficient large phytoplankton (or strong grazing pressure over large phytoplankton) cells (Tremblay \& Legendre 1994). In this case, the tendency towards short-term autotrophy after inorganic nutrient additions was higher than expected from the biomass sizestructure. Hence, our results suggest that knowledge on the contribution of large cells to both biomass and production is important to predict the microbial response to inorganic nutrient inputs.

After organic enrichments, all microbial communities tended towards short-term heterotrophy $\left(P / R_{\mathrm{RR}}\right.$ from 0.2 to 0.8 ) (Fig. 4B). This tendency increased from the upper left corner (low \%chl $a>2 \mu \mathrm{m}$ and high $\% \mathrm{PP}>2 \mu \mathrm{m}$ ) to the lower right corner of the plot (high \%chl $a>2 \mu \mathrm{m}$ and low \%PP $>2 \mu \mathrm{m}$ ), that is, as the efficiency of large phytoplankton decreases (or as the grazing pressure over small phytoplankton increases) (Tremblay \& Legendre 1994). Contrary to our initial hypothesis, microbial food webs dominated by small phytoplankton cells were not more susceptible to heterotrophy after organic matter inputs. Indeed, the strongest tendency to short-term heterotrophy occurred in Expt 8, where large phytoplankton contributed $>80 \%$ to phytoplankton biomass but $<50 \%$ to phytoplankton production, i.e. the production to biomass ratio of large-sized phytoplankton was very low (Martínez-García et al. 2010b). Examples of such planktonic trophic structure highly susceptible to metabolic change can be found in post-bloom situations, where the delayed consumption of the organic matter accumulated after a period of high primary production rates may promote shifts towards heterotrophy of microbial communities (Blight et al. 1995, Smith et al. 1995, Sherr \& Sherr 1996, Serret et al. 1999).

Therefore, as for inorganic nutrient addition, the contribution of large cells to both production and biomass appear to modulate the short-term microbial metabolic balance response after organic additions.

On average, heterotrophic responses $\left(\mathrm{CR}_{\mathrm{RR}}\right)$ were considerably stronger than autotrophic responses $\left(\mathrm{PP}_{\mathrm{RR}}\right)$ after mixed additions in both microbial and herbivore food webs (Table 3 ). Contrary to $P / R$ responses $\left(P / R_{\mathrm{RR}}\right)$ after inorganic or organic inputs, $P / R_{\mathrm{RR}}$ responses after mixed enrichments were not clearly dependent on the initial production and biomass structures of the phytoplankton community (i.e. their position in the $P / B$ plot), but were essentially coupled to initial $P / R$ ratios and ranged from 0.1 (tendency towards short-term heterotrophy) to 1.6 (tendency towards short-term autotrophy) (Fig. 4C): the higher the initial $P / R$, the weaker the tendency towards heterotrophy of microbial communities after mixed additions. Considering that the metabolic balance of microbial communities is controlled by the contribution of large phytoplankton cells to primary production (Serret et al. 2001, Smith \& Kemp 2001, Teira et al. 2001a,b), such a trend may be explained by the positive response of large phytoplankton cells to the combined inorganic and organic nutrient additions (Fig. 2), which would partially compensate the enhanced community respiration.

Phytoplankton biomass and production size-structure (i.e. position on the $P / B$ plot) controls cycling of organic matter through the pelagic ecosystem, because of its influence on carbon export processes (Legendre \& Le Fèvre 1995, Tremblay \& Legendre 1994), on the PER of organic carbon (Teira et al. $2001 \mathrm{a}, \mathrm{b})$ and on the metabolic balance of microbial communities (Serret et al. 2001, Smith \& Kemp 2001, Teira et al. 2001a,b). Our results further suggest that size-fractionated production/biomass of the phytoplankton community also modulates the direction and magnitude of the short-term response of the microbial plankton metabolic balance to different types of nutrient inputs.

A summary of the responses of the metabolic balance to inorganic and/or organic nutrient enrichment in relation to the biomass and production size-structure of the microbial communities and the initial $P / R$ found in the present study is represented in Fig. 5. Herbivore food webs showed the strongest tenden- 
Microbial community structure

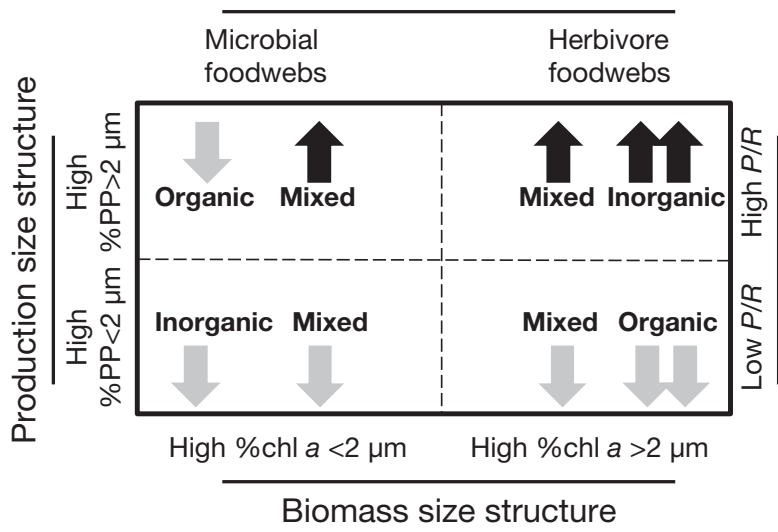

Biomass size structure

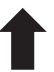

Tendency towards autotrophy after the nutrient addition

Tendency towards heterotrophy after the nutrient addition

Fig. 5. General scheme of the metabolic balance responses to inorganic and/or organic nutrient enrichment in relation to the biomass and production size-structure of microbial communities. Phytoplankton biomass size-structure is represented on the $x$-axis, with high values corresponding to high percentages of chl $a>2 \mu \mathrm{m}$ (lower $x$-axis) and, therefore, herbivore food webs (upper $x$-axis). Phytoplankton production size-structure is represented on the left $y$-axis, with high values corresponding to high percentages of PP $>2 \mu \mathrm{m}$ and high initial $P / R$ ratios (right $y$-axis). Upward black shaded arrows: tendency towards autotrophy after nutrient addition; downward grey shaded arrows: tendency towards heterotrophy after nutrient addition; two arrows: stronger tendencies

cies towards short-term autotrophy and heterotrophy after inorganic and organic inputs, respectively, suggesting a higher sensitivity of the metabolic balance of herbivore food webs to nutrient inputs as compared to microbial food webs. In contrast, the response of the metabolic balance to mixed inputs seemed to be primarily regulated by the initial metabolic balance of microbial communities, regardless of their trophic structure.

Acknowledgements. We thank all the people involved in the projects Trynitrop and AddEx who helped with preparation of the experiments and sampling. We acknowledge the crew of the BO 'Hespérides' and the RV 'Mytilus' for their help during the work at sea. We thank Estación de Ciencias Mariñas de Toralla (ECIMAT) for technical support during the coastal experiments. Access to vessel time for the coastal experiments was provided by the RAFTING project (CTM2007-61983/MAR). This research was supported by a Xunta de Galicia AddEx contract (PGIDIT06PXIB312222PR) and the Ministerio de Educación y Ciencia (MEC) contract TRYNITROP (CTM2004-05174-C02). S.M.G. was funded by a Formación de Profesorado Universitario MEC fellowship. E.T. was founded by a Juan de la Cierva and a Ramón y Cajal-MEC contract.

\section{LITERATURE CITED}

Agawin NSR, Duarte CM, Agustí S (2000) Nutrient and temperature control of the contribution of picoplankton to phytoplankton biomass and production. Limnol Oceanogr 45:591-600

Álvarez-Salgado XA, Rosón G, Pérez FF, Figueiras FG, Pazos Y (1996) Nitrogen cycling in an estuarine upwelling system, the Ria de Arousa (NW Spain). I. Shorttime-scale patterns of hydrodynamic and biogeochemical circulation. Mar Ecol Prog Ser 135:259-273

Álvarez-Salgado XA, Castro CG, Pérez FF, Fraga F (1997) Nutrient mineralization patterns in shelf waters of the western Iberian upwelling. Cont Shelf Res 17:1247-1270

> Azam F, Fenchel T, Field JG, Gray JS, Meyer-Rail LA, Thingstad F (1983) The ecological role of water-column microbes in the sea. Mar Ecol Prog Ser 10:257-263

Baker AR, Weston K, Kelly SD, Voss M, Streu P, Cape JN (2007) Dry and wet deposition of nutrients from the tropical Atlantic atmosphere: links to primary productivity and nitrogen fixation. Deep-Sea Res I 54:1704-1720

Benner R (2002) Chemical composition and reactivity. In: Hansell DA, Carlson CA (eds) Biogeochemistry of dissolved organic matter. Academic Press, San Diego, CA, p 153-231

Blight SP, Bentley TL, Lefevre D, Robinson C, Rodrigues R, Rowlands J, Williams PJleB (1995) Phasing of autotrophic and heterotrophic plankton metabolism in a temperate coastal ecosystem. Mar Ecol Prog Ser 128:61-75

Bonnet S, Guieu C, Chiaverini J, Ras J, Stock A (2005) Effect of atmospheric nutrients on the autotrophic communities in a low nutrient, low chlorophyll system. Limnol Oceanogr 50:1810-1819

Bronk DA (2002) Dynamics of DON. In: Hansell DA, Carlson CA (eds) Biogeochemistry of dissolved organic matter. Academic Press, San Diego, CA, p 153-231

- Calbet A, Laundry MR (2004) Phytoplankton growth, microzooplankton grazing, and carbon cycling in marine systems. Limnol Oceanogr 49:51-57

Calvo-Díaz A, Morán XAG (2009) Empirical leucine-to-carbon conversion factors for estimating heterotrophic bacterial production: seasonality and predictability in a temperate coastal ecosystem. Appl Environ Microbiol 75: 3216-3221

- Carlson CA, Giovannoni SJ, Hansell DA, Goldberg SJ and others (2002) Effect of nutrient amendments on bacterioplankton production, community structure, and DOC utilization in the northwestern Sargasso Sea. Aquat Microb Ecol 30:19-36

Cauwet G (2002) DOM in the coastal zone. In: Hansell DA, Carlson CA (eds) Biogeochemistry of marine dissolved organic matter. Academic Press, San Diego, CA, p 579-609

> Cermeño P, Marañón E, Rodríguez J, Fernández E (2005) Large-sized phytoplankton sustain higher carbonspecific photosynthesis than smaller cells in a coastal eutrophic ecosystem. Mar Ecol Prog Ser 297:51-60

Cermeño P, Marañón E, Pérez V, Serret P, Fernández E, Castro CG (2006) Phytoplankton size structure and primary production in a highly dynamic coastal ecosystem (Ría de Vigo, NW Spain): seasonal and short-time scale variability. Estuar Coast Shelf Sci 67:251-266

Davidson K, Gilpin LC, Hart MC, Foilland E and others (2007) The influence of the balance of inorganic and organic nitrogen on the trophic dynamics of microbial food webs. Limnol Oceanogr 52:2147-2163 
Downing JA, Osenberg CW, Sarnelle O (1999) Metaanalysis of marine nutrient-enrichment experiments: variation in the magnitude of nutrient limitation. Ecology 80:1157-1167

Elser JJ, Bracken MES, Cleland EE, Gruner DS and others (2007) Global analysis of nitrogen and phosphorus limitation of primary producers in freshwater, marine and terrestrial ecosystems. Ecol Lett 10:1135-1142

Fanning KA (1992) Nutrient provinces in the sea: concentration ratios, reaction rate ratios, and ideal covariation. J Geophys Res 97:5693-5712

Fenchel T (2008) The microbial loop - 25 years later. J Exp Mar Biol Ecol 366:99-103

Gasol JM, del Giorgio PA (2000) Using flow cytometry for counting natural planktonic bacteria and understanding the structure of planktonic bacterial communities. Sci Mar 64:197-224

> Graziano LM, Geider RJ, Li WKW, Olaizola M (1996) Nitrogen limitation of North Atlantic phytoplankton: analysis of physiological condition in nutrient enrichment experiments. Aquat Microb Ecol 11:53-64

> Gregg MC, Sanford TB, Winkel DP (2003) Reduced mixing from the breaking of internal waves in equatorial waters. Nature 422:513-515

Hansen HP, Grasshoff K (1983) Automated chemical analysis. In: Grasshoff K, Ehrhardt M, Kermling K (eds) Methods of seawater analysis, 2nd edn. Verlag Chemie, Weinheim, p 347-395

Hedges LV, Gurevitch J, Curtis PS (1999) The meta-analysis of response ratios in experimental ecology. Ecology 80: 1150-1156

Herut B, Zohary T, Krom MD, Mantourad RFC and others (2005) Response of Mediterranean surface water to Saharan dust: on-board microcosm experiment and field observations. Deep-Sea Res II 52:3024-3040

- Joint I, Henriksen P, Fonnes GA, Bourne D, Thingstad TF, Riemann B (2002) Competition for inorganic nutrients between phytoplankton and bacterioplankton in nutrient manipulated mesocosms. Aquat Microb Ecol 29: 145-159

Karl DM, Laws EA, Morris P, Williams PJleB, Emerson S (2003) Metabolic balance of the open sea. Nature 426:32

$>$ Kerouel R, Aminot A (1997) Fluorometric determination of ammonia in sea and estuarine waters by direct segmented flow analysis. Mar Chem 57:265-275

Kiørboe T (1996) Material flux in the water column. In: Jongersen BB, Richardson K (eds) Eutrophication in coastal ecosystems. Coastal and Marine Studies, Vol 52, AGU, Washington, DC, p 67-94

Kirchman D, Knees E, Hodson R (1985) Leucine incorporation and its potential as a measure of protein synthesis by bacteria in natural aquatic systems. Appl Environ Microbiol 49:599-607

Legendre L (1990) The significance of microalgal blooms for fisheries and for the export of particulate organic carbon in oceans. J Plankton Res 12:681-699

> Legendre L, Le Fèvre J (1995) Microbial food webs and the export of biogenic carbon in the oceans. Aquat Microb Ecol 9:69-77

> Legendre L, Rassoulzadegan F (1996) Food-web mediated export of biogenic carbon in oceans: hydrodynamic control. Mar Ecol Prog Ser 145:179-193

> Lekunberri I, Lefort T, Romero E, Vázquez-Domíngez E and others (2010) Effects of a dust deposition event on coastal marine microbial abundance and activity, bacterial com- munity structure and ecosystem function. J Plankton Res 32:381-396

- Marañón E, Holligan PM, Barciela R González N, Mouriño B, Pazó MJ, Varela M (2001) Patterns of phytoplankton size structure and productivity in contrasting open-ocean environments. Mar Ecol Prog Ser 216:43-56

> Marañón E, Cermeño P, Fernández E, Rodríguez J, Zabala L (2004) Significance and mechanisms of photosynthetic production of dissolved organic carbon in a coastal eutrophic ecosystem. Limnol Oceanogr 49:1652-1666

Marañón E, Fernández A, Huete-Ortega M, Mouriño-Carballido B and others (2010) The degree of oligotrophy controls the response of microbial plankton to Saharan dust. Limnol Oceanogr 55:2339-2352

- Martínez-García S, Fernández E, Aranguren-Gassis M, Teira E (2009) In vivo electron transport system activity: a method to estimate respiration in marine microbial planktonic communities. Limnol Oceanogr Methods 7:459-469

Martínez-García S, Fernández E, Calvo-Díaz A, Marañón E, Morán XAG, Teira E (2010a) Response of heterotrophic and autotrophic microbial plankton to inorganic and organic inputs along a latitudinal transect in the Atlantic Ocean. Biogeosciences 7:1701-1713

- Martínez-García S, Fernández E, Álvarez-Salgado XA, González J and others (2010b) Differential responses of phytoplankton and heterotrophic bacteria to organic and inorganic nutrient additions in coastal waters off the NW Iberian Peninsula. Mar Ecol Prog Ser 416:17-33

McGillicuddy DJ, Robinson AR, Siegel DA, Jannasch HW and others (1998) Influence of mesoscale eddies on new production in the Sargasso Sea. Nature 394:263-266

Michaels AF, Siegel DA, Johnson RJ, Knap AH, Galloway JN (1993) Episodic inputs of atmospheric nitrogen to the Sargasso Sea: contributions to new production and phytoplankton blooms. Global Biogeochem Cycles 7:339-351

Mills MM, Ridame C, Davey M, La Roche J, Geider RJ (2004) Iron and phosphorus co-limit nitrogen fixation in the eastern tropical North Atlantic. Nature 429:292-294

Moore CM, Mills MM, Milnes A, Langlois R and others (2006) Iron limits primary productivity during spring bloom development in the central North Atlantic. Glob Change Biol 12:626-634

> Moore CM, Mills MM, Langlois R, Milne A, Achterberg EP, La Roche J, Geider RJ (2008) Relative influence of nitrogen and phosphorus availability on phytoplankton physiology and productivity in the oligotrophic sub-tropical North Atlantic Ocean. Limnol Oceanogr 53:291-305

> Nogueira E, Pérez FF, Ríos AF (1997) Seasonal patterns and long-term trends in an estuarine ecosystem (Ría de Vigo, NW Spain). Estuar Coast Shelf Sci 44:285-300

> Piehler MF, Twomey LJ, Hall NS, Paerl HW (2004) Impacts of inorganic nutrient enrichment on phytoplankton community structure and function in Pamlico Sound, NC, USA. Estuar Coast Shelf Sci 61:197-209

> Platt T, Rao DVS, Irwin B (1983) Photosynthesis of picoplankton in the oligotrophic ocean. Nature 301:702-704

Prego R, Barciela MC, Varela M (1999) Nutrient dynamics in the Galician coastal area (northwestern Iberian Peninsula): Do the Rias Bajas receive more nutrient salts than the Rias Altas? Cont Shelf Res 19:317-334

> Pulido-Villena E, Wagener T, Guieu C (2008) Bacterial response to dust pulses in the western Mediterranean: implications for carbon cycling in the oligotrophic ocean. Global Biogeochem Cycles 22:GB1020, doi:10.1029/ 2007GB003091 
Raimbault P, Slawyk G, Coste B, Fry J (1990) Feasibility of using an automated colorimetric procedure for the determination of seawater nitrate in the 0 to $100 \mathrm{nM}$ rangeexamples from field and culture. Mar Biol 104:347-351

Reche I, Ortega-Retuerta E, Romera O, Pulido-Villena E, Morales-Baquero R, Casamayor E (2009) Effect of Saharan dust inputs on bacterial activity and community composition in Mediterranean lakes and reservoirs. Limnol Oceanogr 54:869-879

Serret P, Fernández E, Sostres JA, Anadón R (1999) Seasonal compensation of microbial production and respiration in a temperate sea. Mar Ecol Prog Ser 187:43-57

Serret P, Robinson C, Fernández E, Teira E, Tilstone G (2001) Latitudinal variation of the balance between plankton photosynthesis and respiration in the eastern Atlantic Ocean. Limnol Oceanogr 46:1642-1652

Sherr E, Sherr BF (1996) Temporal offset in oceanic production and respiration processes implied by seasonal changes in atmospheric oxygen: the role of heterotrophic microbes. Aquat Microb Ecol 11:91-100

Sherr E, Sherr B (2000) Marine microbes: an overview. In: Kirchman DL (ed) Microbial ecology of the oceans, 1st edn. Wiley-Liss, New York, NY, p 13-46

Smith DC, Azam F (1992) A simple, economical method for measuring bacterial protein synthesis rates in seawater using ${ }^{3} \mathrm{H}$-leucine. Mar Microb Food Webs 6:107-114

Smith DC, Steward GF, Long RA, Azam F (1995) Bacterial mediation of carbon fluxes during a diatom bloom in a mesocosm. Deep-Sea Res II 42:75-97

Smith EM, Kemp WM (2001) Size-structure and the production/respiration balance in a coastal plankton community. Limnol Oceanogr 46:473-485

Sokal RR, Rohlf FJ (1995) Biometry: the principles and practice of statistics in biological research, 3rd edn. Freeman, New York, NY

Steele JH (1976) The structure of marine ecosystems. Harvard University Press, Cambridge, MA

Teira E, Pazó MJ, Serret P, Fernández E (2001a) Dissolved

Editorial responsibility: William Kemp,

Cambridge, Maryland, USA organic carbon production by microbial populations in the Atlantic Ocean. Limnol Oceanogr 46:1370-1377

Teira E, Serret P, Fernández E (2001b) Phytoplankton sizestructure, particulate and dissolved organic carbon production and oxygen fluxes through microbial communities in the NW Iberian coastal transition zone. Mar Ecol Prog Ser 219:65-83

Teira E, Mouriño B, Marañón E, Pérez V and others (2006) Variability of chlorophyll and primary production in the eastern North Atlantic Subtropical Gyre: potential factors affecting phytoplankton activity. Deep-Sea Res I 52: 569-588

Thingstad TF, Sakshaug E (1990) Control of phytoplankton growth in nutrient recycling ecosystems. Theory and terminology. Mar Ecol Prog Ser 63:261-272

Thingstad TF, Havskum H, Kaas H, Nielsen TG, Riemann B, Le Févre D, Williams PJleB (1999) Bacteria-protist interactions and organic matter degradation under P-limited conditions: analysis of an enclosure experiment using a simple model. Limnol Oceanogr 44:62-79

Tréguer P, Le Corre P (1975) Manuel d'analyse des sels nutritifs dans l'eau de mer. Utilisation de l'auto analyseur II, Technicon. L.O.C. Université Bretagne Occidentale, Brest

Tremblay JE, Legendre L (1994) A model for the sizefractionated biomass and production of marine phytoplankton. Limnol Oceanogr 39:2004-2014

Uz BM, Yoder JA, Osychny V (2001) Pumping of nutrients to ocean surface waters by the action of propagating planetary waves. Nature 409:597-600

Vargas CA, Martínez RA, Cuevas LA, Pavez MA and others (2007) The relative importance of microbial and classical food webs in a highly productive coastal upwelling area. Limnol Oceanogr 52:1495-1510

Williams PJleB, del Giorgio PA (2005) Respiration in aquatic ecosystems: history and background. In: del Giorgio PA, Williams PJleB (eds) Respiration in aquatic ecosystems. Oxford University Press, London, p 1-18

Submitted: June 27, 2011; Accepted: May 10, 2012

Proofs received from author(s): August 12, 2012 